\title{
Comparative Evaluation and Correlation of Salivary Total Antioxidant Capacity and Salivary pH in Caries-free and Severe Early Childhood Caries Children
}

\author{
${ }^{1}$ Sneha Muchandi, ${ }^{2}$ Hrishikesh Walimbe, ${ }^{3}$ Mohammed Nadeem Ahmed Bijle, ${ }^{4}$ Meenakshi Nankar \\ ${ }^{5}$ Srishti Chaturvedi, ${ }^{6}$ Priyanka Karekar
}

\begin{abstract}
Background: Dental caries is a major problem in preschool children. The contribution of saliva in providing defense during caries process is of primary importance. pH buffer capacity through bicarbonate, phosphate and protein buffer systems have universal acceptance as a caries defense mechanism. Antioxidant capacity of saliva can constitute a first line of defense against chronic degenerative diseases including dental caries. Till date, no study is presented with salivary antioxidant capacity of younger children affected with severe early childhood caries with its salivary $\mathrm{pH}$ correlation. Hence, this study was carried out to compare, evaluate and correlate the salivary total antioxidant capacity (TAC) and salivary $\mathrm{pH}$ of children with caries-free and severe early childhood caries.
\end{abstract}

Materials and methods: Fifty children from ages 3 to 5 years divided into two study groups had undergone screening. Group I $(n=25)$ with severe early childhood caries (S-ECC) and group II $(n=25)$ who were caries free. Unstimulated whole saliva of subjects were in the collection during the study by draining method. Salivary $\mathrm{pH}$ determination of saliva samples was done using $\mathrm{pH}$ indicator paper strips. The TAC was done using an antioxidant assay with the help of a spectrophotometer at wavelength $532 \mathrm{~nm}$. The means of salivary $\mathrm{pH}$ and TAC were subjected to analysis using unpaired student ' $t$ ' test and correlation was determined using Pearsons correlation coefficient analysis.

Results: Mean salivary $\mathrm{pH}$ was higher in group II (7.46 \pm 0.37$)$. Mean TAC was greater in group I (1.82 \pm 0.19$)$. A statistically significant negative correlation as seen between TAC and salivary $\mathrm{pH}$ in S-ECC patients.

Conclusion: The study concludes that salivary TAC increases in patients with S-ECC are by that showing a high indirect relationship with salivary $\mathrm{pH}$.

Keywords: Dental caries, Oxidative stress, Saliva

1,2,4-6 Department of Pedodontics and Preventive Dentistry, Dr DY Patil Dental College and Hospital, Dr DY Patil Vidyapeeth Pune, Maharashtra, India

${ }^{3}$ Department of Preventive Dental Sciences, Division of Pedodontics, King Khalid University, College of Dentistry Abha, Saudi Arabia

Corresponding Author: Mohammed Nadeem Ahmed Bijle, Assistant Professor, Department of Preventive Dental Sciences, Division of Pedodontics, King Khalid University College of Dentistry, Abha, Saudi Arabia, Phone: + 966-(0)504217533, e-mail: info@drnadeembijle.com
How to cite this article: Muchandi S, Walimbe $\mathrm{H}$, Bijle MNA, Nankar M, Chaturvedi S, Karekar P. Comparative Evaluation and Correlation of Salivary Total Antioxidant Capacity and Salivary $\mathrm{pH}$ in Caries-free and Severe Early Childhood Caries Children. J Contemp Dent Pract 2015;16(3):234-237.

Source of support: Nil

Conflict of interest: None

\section{INTRODUCTION}

Dental caries, a chronic infectious disease affecting hard tissues of the oral cavity is an important oral health problem in most countries. ${ }^{1}$ Nonetheless, it is a major problem in preschool children. The highly susceptible nature of the group would have a contributing factor as immature enamel due to its newly-erupted kind. In addition, there are other contributing factors that also play a role as etiological agents being cariogenic microorganisms, tooth susceptibility, cariogenic diet and its frequency distribution, newly established bacterial flora and immature host defense systems. ${ }^{2,3}$ Among pre-school children, dental caries evident is early childhood caries (ECC). Its severe form is severe early childhood caries (S-ECC) affecting very young individuals aged less than 3 years. ${ }^{3}$

The contribution of saliva in providing defense during caries process is of primary importance. Saliva marks protection due to its antimicrobial activity, $\mathrm{pH}$ buffering capacity, salivary flow rate, flow related clearance of diet and immunological defense system. However, the immune defense system is immature in young children with its instability of microflora thus, contributing no benefit to the caries process in the population of concern. Flow related clearance of diet is a dependent variable on other defense mechanism and hence, has no role of its own. Salivary flow rate is an independent variable and has its marked influence on other protective factors. $\mathrm{pH}$ buffering capacity and antimicrobial activity are also dependent on flow rate but have their set mechanisms of protection. Of which, antimicrobial activity has a significant contribution to salivary proteins namely lysozyme, agglutinin, lactoferrins and histatins that have been widely studied. The systemic influence on antimicrobial activity is also a known fact and has 
received considerable acceptance years before. ${ }^{4} \mathrm{pH}$ buffer capacity through bicarbonate, phosphate and protein buffer systems have universal acceptance and due recognition as a definite dependent variable on salivary flow rate.

Of factors fore stated, salivary flushing and buffering capacity form the most significant caries preventive functions. Although, salivary flushing has a direct dependent variable on flow rate, which is eventually low in young children with primary dentition as compared to their counterparts with mixed dentition. Thus, ruling out the salivary flushing benefit in the prevention of early childhood caries. ${ }^{5}$ Buffering capacity of the saliva is been a direct associative factor with increase in dental caries in children and adolescence. ${ }^{6}$ However, its actual relation to severe early childhood caries — the most aggressive form in young children is yet to be evident.

Clinicians and researchers in recent years have diverted their attention toward the antioxidant capacity of saliva that can constitute a first line of defense against chronic degenerative diseases including dental caries. Chronic illnesses mark by production of free radicals (FR) or reactive oxygen species (ROS) regarded as oxidative stress. Salivary antioxidants are capable of interacting with levels of FR/ROS in order to limit disease progression. When imbalances are certain between antioxidants and FR/ROS, the onset of the ailment is in stage. Thus, there seems a concerted relationship between antioxidants and FR/ROS.

Till date, no study is presented with salivary antioxidant capacity of younger children affected with severe early childhood caries with its salivary $\mathrm{pH}$ correlation. Such a study would show a correlative parameter for the diagnosis in highly susceptible young children and implementation of necessary measures thereof.

Hence, this study was carried out to compare, evaluate and correlate the salivary total antioxidant capacity (TAC), and salivary $\mathrm{pH}$ of children with caries-free and severe early childhood caries.

\section{MATERIALS AND METHODS}

Children from ages 3 to 5 years studying in Dr DY Patil Public School, Pimpri, Pune had undergone screening. Following a preliminary examination through randomization of subjects, total of 50 children were selected and accordingly divided into two study groups. Group I $(n=25)$ with severe early childhood caries (S-ECC) and group II $(n=25)$ who were caries free. A mandatory requirement set a receipt of written informed consent from the ward's parents as per mentioned in Schedule $Y$ given by World Health Organization (WHO) before com- mencement of the study. Children with compromised conditions, systemic diseases, local infections, any term medication that thereby influence salivary secretions and flow rate were excluded from the study. ${ }^{8-10}$

Of various methods available, unstimulated whole saliva of subjects were in the collection during the study by draining method till mark 2 to $3 \mathrm{ml}$ in sterile tubes. The draining method so far has maximum acceptability for unstimulated collection. All necessary protocols for collection were in place. ${ }^{11}$ Following collection, immediate $\mathrm{pH}$ determination of saliva samples using $\mathrm{pH}$ indicator paper strips (Qualigens, Glaxo India Ltd, Mumbai, India) was due in the process. The $\mathrm{pH}$ as noted was based on the color change in comparison to the gold standard chart provided by the manufacturer. The salivary samples stored in a container with a maintained $4^{\circ} \mathrm{C}$ temperature were transported within 1 hour of collection to the laboratory for estimation of TAC.

The TAC was done using an antioxidant assay with the help of a spectrophotometer at wavelength $532 \mathrm{~nm}$ proposed by Koracevic et al. ${ }^{12}$ This method requires less sample and is accessible to routine use. The assay is based on measurement of TAC of saliva using the property of inhibition of production of thiobarbituric acid reactive substances (TBARS) by the fluid.

\section{STATISTICAL ANALYSIS}

The statistical analysis was done using the SPSS $\mathrm{v} 17$ (Statistical Package for Social Science, IBM, Chicago, Illinois, USA). Descriptive statistics (mean and standard deviation) were calculated for salivary $\mathrm{pH}$ and TAC of saliva. Unpaired student ' $t$ ' test was used to compare the salivary $\mathrm{pH}$ and TAC of unstimulated whole saliva between the two study groups, i.e. group I (children with severe early childhood caries) and group II (caries-free children). Pearson's correlation coefficient was used to analyze the correlation between salivary $\mathrm{pH}$ and TAC of saliva in each of the two study groups.

\section{RESULTS}

Mean salivary $\mathrm{pH}$ in group II (caries free) was higher as compared to the average salivary $\mathrm{pH}$ level in group I (S-ECC) (Table 1). This difference in the average salivary $\mathrm{pH}$ in the two groups was found to be statistically significant ( $\mathrm{p}$-value $<0.0001$ ). Mean TAC of saliva in group I was higher in comparison with group II, thereby the difference to be statistically significant ( $p$-value $<0.0001$ ) (Table 2). A negative correlation was found between both the groups; however, the relation in group I was statistically significant as per Pearson's correlation coefficient analysis (p-value < 0.05) (Table 3) (Graphs 1 and 2). 


\begin{tabular}{|c|c|c|c|c|}
\hline & Group I & Group II & & \\
\hline Parameter & $\begin{array}{l}\text { Mean } \pm S D \\
(n=25)\end{array}$ & $\begin{array}{l}\text { Mean } \pm S D \\
(n=25)\end{array}$ & $t$-value & $p$-value \\
\hline Salivary $\mathrm{pH}$ & $6.42 \pm 0.34$ & $7.46 \pm 0.37$ & 10.39 & $<0.0001$ \\
\hline \multicolumn{5}{|c|}{ Unpaired Student t-test; $p$-value $<0.0001$} \\
\hline \multicolumn{5}{|c|}{$\begin{array}{l}\text { Table 3: Correlation between salivary } \mathrm{pH} \text { and total antioxidant } \\
\text { capacity of saliva in Group I (S-ECC) and Group II (Caries free) }\end{array}$} \\
\hline \multicolumn{3}{|c|}{$\begin{array}{l}\text { Correlation between salivary } \mathrm{pH} \text { and total } \\
\text { antioxidant capacity (TAC) of saliva }\end{array}$} & value & $p$-value \\
\hline \multicolumn{3}{|l|}{ Group I } & 0.47 & $<0.05$ \\
\hline \multicolumn{3}{|l|}{ Group II } & 0.20 & $>0.05$ \\
\hline
\end{tabular}

Pearson's correlation coefficient analysis; $p$-value $<0.05$

\section{DISCUSSION}

The results of the present study show an increase in TAC levels of saliva in patients with S-ECC as compared to the caries-free children showing direct relationship between activities, thereby rationalizing the infectious challenge. The determination of the problem can be attributed to

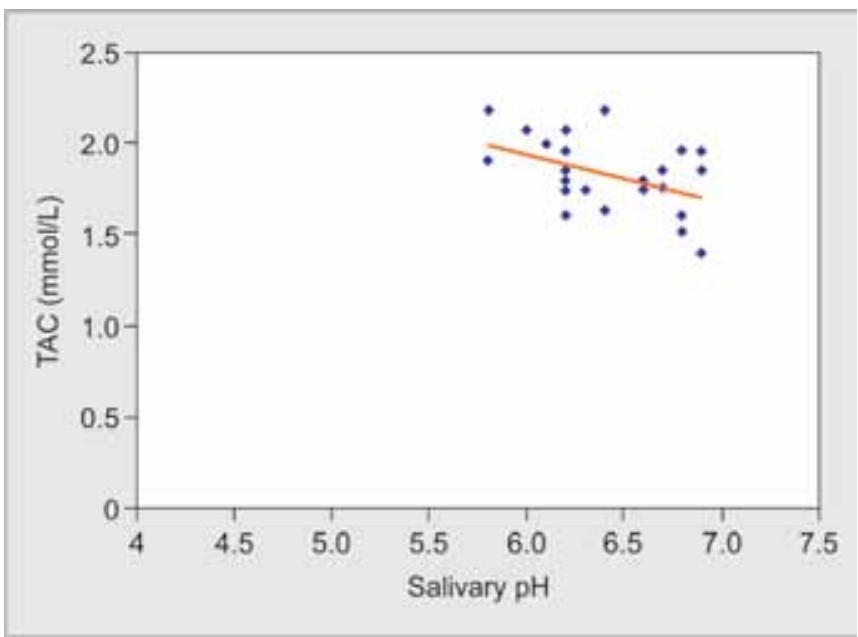

Graph 1: Correlation between salivary $\mathrm{pH}$ and total antioxidant capacity of saliva in group I (S-ECC)

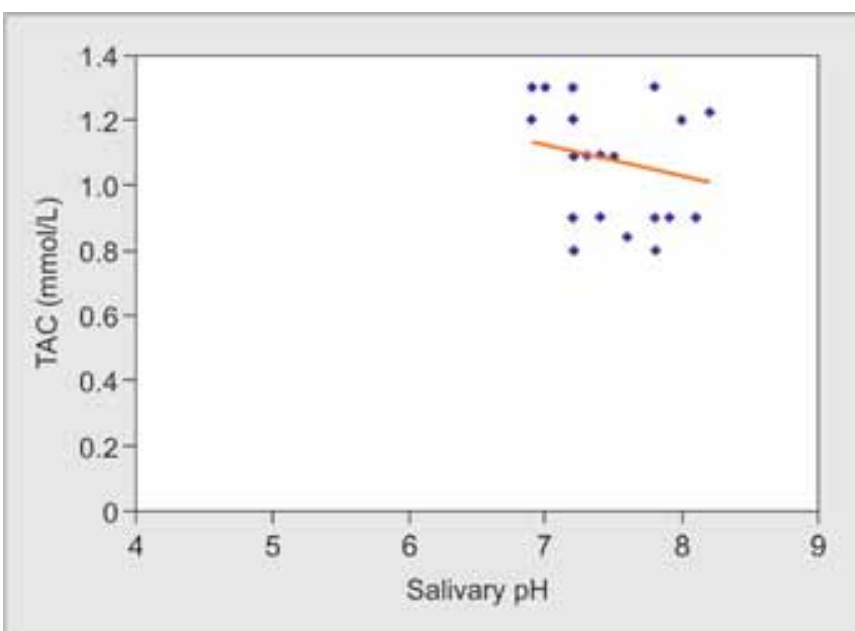

Graph 2: Correlation between salivary $\mathrm{pH}$ and total antioxidant of saliva in group II (Caries-free)
Table 2: Comparison of total antioxidant capacity of saliva in group I (S-ECC) and group II (Caries-free)

\begin{tabular}{llllll}
\hline & Group I & Group II & & \\
\cline { 2 - 4 } & $\begin{array}{l}\text { Mean } \pm S D \\
(n=25)\end{array}$ & $\begin{array}{l}\text { Mean } \pm S D \\
(n=25)\end{array}$ & t-value & $p$-value \\
\hline Parameter & $\begin{array}{l}\text { Total antioxidant } \\
\text { capacity (TAC) of } \\
\text { saliva (mmol/l) }\end{array}$ & $1.82 \pm 0.19$ & $1.08 \pm 0.17$ & 14.29 & $<0.0001$ \\
\hline
\end{tabular}

Unpaired Student t-test; $p$-value $<0.0001$

the relationship influencing TAC due to FR/ROS in an infectious environment. ${ }^{7}$ The results are in concordance with other studies by Tulunoglu et al ${ }_{1}^{13}$ Kumar et $\mathrm{al}^{14}$ and Dodwad et al. ${ }^{15}$

A statistically significant negative correlation, as seen between TAC and salivary $\mathrm{pH}$ in S-ECC patients, indicates definitive relationship between the parameters of the disease. However, a further exploration of individual antioxidants and salivary $\mathrm{pH}$ relationship could answer the condition better. The results are in agreement with the study done by Preethi et al. ${ }^{16}$

The results obtained in the present study indicate that any alterations in the physicochemical properties of saliva, such as $\mathrm{pH}$ and the antioxidant defense system play a significant role in the development of caries. For this reason, if the antioxidant imbalances are predetermined or regularly analyzed can stand as a valuable diagnostic tool for pathologic challenge determination. The determination can, thereby help one to implement protocols for control of disease.

\section{CONCLUSION}

The study concludes with the following:

- Salivary TAC increases in patients with S-ECC.

- There seems to be a strong indirect relationship between TAC and salivary $\mathrm{pH}$ in patients with S-ECC.

\section{REFERENCES}

1. Petersen PE. The World Oral Health Report 2003: continuous improvement of oral health in the 21st century-the approach of the WHO Global Oral Health Programme. Community Dent Oral Epidemiol 2003;31 (Suppl 1):3-23.

2. Vadiakas G. Case definition, aetiology and risk assessment of early childhood caries (ECC): a revisited review. Eur Arch Paediatr Dent 2008;9(3):114-125.

3. Group O, Council R. Policy on early childhood caries (ECC): classifications, consequences, and preventive strategies. Pediatr Dent 2014;30(6):40-43.

4. Lenander-Lumikari M, Loimaranta V. Saliva and dental caries. Adv Dent Res 2000;14(1):40-47.

5. Bretz W a, do Valle EV, Jacobson JJ, Marchi F, Mendes S, Nor JE, et al. Unstimulated salivary flow rates of young children. Oral Surg Oral Med Oral Pathol Oral Radiol Endod 2001;91(5):541-545.

6. Cunha-Cruz J, Scott J, Rothen M, Mancl L, Lawhorn T, Brossel K, et al. Salivary characteristics and dental caries: evidence from general dental practices. J Am Dent Assoc 2013;144(5):e31-40. 
7. Battino M, Ferreiro MS, Gallardo I, Newman HN, Bullon P. The antioxidant capacity of saliva. J Clin Periodontol 2002;29(3):189-194.

8. Sreebny LM, Schwartz SS. A reference guide to drugs and dry mouth. Gerodontology 1986;5(2):75-99.

9. Sreebny LM, Schwartz SS. A reference guide to drugs and dry mouth. 2nd ed. Gerodontology 1997;14(2):33-47.

10. Mandel ID. The Diagnostic uses of saliva. J Oral Pathol Med 1990;19(3):119-125.

11. Navazesh M. Methods for collecting saliva. Ann NY Acad Sci 199;694(9):72-77.

12. Koracevic D, Koracevic G, Djordjevic V, Andrejevic S, Cosic V. Method for the measurement of antioxidant activity in human fluids. J Clin Pathol 2001;54(1):356-361.
13. Tulunoglu Ö, Demirtas S, Tulunoglu I. Total antioxidant levels of saliva in children related to caries, age, and gender. Int J Paediatr Dent 2006;16(3):186-191.

14. Kumar D, Pandey RK, Agrawal D, Agrawal D. An estimation and evaluation of total antioxidant capacity of saliva in children with severe early childhood caries. Int J Paediatr Dent 2011;21(6):459-464.

15. Dodwad R, Betigeri A, Preeti B. Estimation of total antioxidant capacity levels in saliva of caries-free and cariesactive children. Contemp Clin Dent 2011;2(1):17.

16. Preethi BP, Reshma D, Anand P. Evaluation of flow rate, $\mathrm{pH}$, buffering capacity, calcium, total proteins and total antioxidant capacity levels of saliva in caries free and caries active children: An in vivo study. Indian J Clin Biochem 2010;25(4):425-428. 